\title{
Research and Development Project Management Practices and
}

\section{Absorptive Capacity: Empirical Evidence from Spanish Firms}

Silvia Vicente-Oliva: silviav@unizar.es; Ángel Martínez-Sánchez; Luis Berges-Muro

\begin{abstract}
Evidence from a study carried out in a sample of Spanish firms indicates that research and development (R\&D) project management practices are positively related to absorptive capacity of knowledge $(A C)$, although the influence of these practices differs for each $A C$ dimension. Managers realize that learning from past experiences in R\&D projects develops the capacity to gain access to relevant external knowledge. However, the positive relationship between management practices and absorptive capacity is only significant for transforming and exploiting external knowledge in R\&D projects. The article discusses the managerial implications of improving absorptive capacity within the management of R\&D projects and the firm, for every AC dimension.
\end{abstract}

\section{Highlights}

- Can the R\&D project management practices improve the absorptive capacity of a firm?

- Generating absorptive capacity is essential, although its achievement is not a project's aim

- Project management contributes positively to absorptive capacity of the firm

Key words: absorptive capacity; knowledge management; managerial practices; R\&D project management 


\section{Introduction}

The innovation literature highlights the importance of external knowledge for solving technical problems within a firm. Innovation management frequently involves the integration of knowledge from market demand and scientific and technological developments (Rohrbeck \& Schwarz, 2013). Thereby, there is a pressure to bring products to the market, at the same time as facing uncertainties on market, technologies, production costs, and the development process itself (Balachandra \& Friar, 1997). This means that firms increasingly need more new external knowledge which may be hard to find, assimilate and include in research and development (R\&D) projects, and it could even consume unexpected resources.

From a strategic perspective, the resources based view of the firm is considered a framework for explaining how organizations achieve sustainable competitive advantages throughout the accumulation of valuable, rare, inimitable and non-substitutable resources (Armstrong \& Shimizu, 2007; J. B. Barney, 2001; J. Barney, 1991; Wernerfelt, 1984). However, the firms can create, extend, or modify its resources base on purpose (Helfalt et al., 2007) by acquiring and using new knowledge, thanks to their dynamic capabilities. These are characterized by the 'firm's abilities to integrate, build, and reconfigure internal and external competences to address rapidly changing environments' (Teece, Pisano, \& Shuen, 1997, p. 516). Moreover, the dynamic capabilities are the antecedent to the organizational and strategic routines (Eisenhardt \& Martin, 2000) and they have been applied lately to Project Management, i.e. Killen, Jugdev, Drouin, \& Petit (2012), LealRodríguez, Roldán, Ariza-Montes, \& Leal-Millán (2014).

The absorptive capacity of knowledge (AC) is considered a dynamic capability by some scholars (Escribano, Fosfuri, \& Tribó, 2009; Fosfuri \& Tribó, 2008). It may also contribute to R\&D project performance by taking into account the external influences as a learning factor (Biedenbach \& Müller, 2012), and it is a related concept to creativity and organizational 
learning at a micro level (Ojo, Raman, Chong, \& Chong, 2014). The capacity of a firm to evalue and acquire external knowledge is called Potential Absorptive Capacity (PAC), whereas Realized Absorptive Capacity (RAC) reflects the firm's capacity to leverage absorbed knowledge and exploit it into innovation (Arora \& Gambardella, 1994; Cassiman \& Veugelers, 2006; Jansen, Van Den Bosch, \& Volberda, 2005; Zahra \& George, 2002).

PAC is considered to be a process of combining capabilities. It is a determinant of strategic innovation, and an antecedent of organizational learning (Gebauer, Worch, \& Truffer, 2012; Lane \& Lubatkin, 1998). Knowledge acquired by exploration activities could sustain R\&D actions and allow new competences to be developed (Danneels, 2002, p. 1104). RAC is effective in using the resources and competences incorporated into a firm in the short-term, but firms cannot exploit knowledge that has not previously been assimilated (March, 1991). Exploitation activities are related to organizational learning (Sitkin, Sutcliffe, \& Schroeder, 1994) because acquired knowledge is a resource that is ready to be used inside the firm. However, each dimension of $A C$ is related to innovation outputs in a different way, and therefore project teams may experience difficulties in managing the levels of PAC and RAC (Jansen et al., 2005).

The relevance of management theories for managerial practice is a topic of frequent debate in academic journals and at professional conferences (Blomquist, Hällgren, Nilsson, \& Söderholm, 2010). Nevertheless, we have found a gap in the theory between managerial practices in R\&D projects and the creation of AC. Although there has previously been some empirical analysis (e.g., Besner \& Hobbs, 2012) that identifies groups of project management toolsets for different types of projects, and a few theoretical insights that discuss how organizations are able to learn from their projects, we think there is still insufficient practical, insightful and scholarly knowledge that explains the contribution of R\&D project managers to a firm's capability to acquire, transform and exploit external knowledge (Bakker, Cambré, Korlaar, \& Raab, 2011; Biedenbach \& Müller, 2012; Mitchell, 
2006). The aim of our research as a whole is to provide an answer to the question: 'Can project management practices improve the AC of a firm in any way?'

In order to answer this research question, we have used the dialogical model that was designed to allow a dialogue between practitioners and researchers who offer complementary visions of a research question (Avenier \& Cajaiba, 2012). According to this model, we first identify the gap in academic research and then we formulate the appropriate research question. The dialogue between academics and experts shows that research topics can be contrasted with practical experience, and that is able to extrapolate from that dialogue in order to reach conclusions. The Avenier's model sets the construction of the conceptual knowledge after the elaboration of local knowledge that we base on an interviews carried out to practitioners (project managers). After that, we communicate the results to academic and professional audiences through specialized media, in order to inform the practitioners and obtain their feedback. The last step of the model is the knowledge activation to put them to practical use, 'it can permit the appropriation of the knowledge, i.e. the integration of this knowledge intro the individual's prior knowledge' (Avenier, 2009), and our joint efforts are driven toward it throughout the collaboration with regional associations.

We structure the paper as follows. In the next section, we review the literature on R\&D project management related to organizational learning and $A C$, in the light of the knowledge context inside a firm. After that, we describe the research methodology and the procedure for data collection. Finally, we present our analytical results and discuss them on the basis of the theoretical and managerial insights. 


\section{R\&D project management and absorptive capacity}

As a result of increasing competitive pressures, many firms nowadays are modifying their technology strategies. Furthermore, they are emphasizing the flexibility of their organizations, adopting improved processes, and focusing more on consumers, with customized goods and services. At the same time, firms also need more new ideas for adopting technologies, accessing new markets, and implementing business models, so they put pressure on their R\&D departments (among others) to initiate and implement projects to fulfil these demands. A project is described by Dvir and Shenhar (1996) as an organizational concept that triggers the process of resolving new problems and improving organizational capabilities (Koskinen, 2011; Wang \& Ahmed, 2007). R\&D projects have increased in complexity (Gunasekaran, 1997) and widened their focus; they now have a vision of a future state (Turner, 2009, p. 2) for the products and processes of a firm and its organizational structure.

The most striking feature of $R \& D$ projects is the fact that the outcomes might be very different from the initial specification but still valuable for the firm (UNE166.001, 2006). International associations like the Project Management Institute (PMI) and the International Project Management Association (IPMA) promote the standardization of project management, although they respect the singularities of each project. According to Project Management Body of Knowledge (PMBOK) (Project Management Institute, 1987) many managerial practices like the definition of responsibilities, cost estimate and control, and resources and time planning (and re-planning) are frequent among all kinds of projects. However, managing some legal issues such as Intellectual Property Rights (IPR), standard certifications for new electromagnetic products, phases for the approval pharmaceutical products, strategies for the exploitation of results, etc. may be susceptible to separate studies of R\&D projects. 


\subsection{R\&D Managerial practices and organizational learning}

The methodologies and components of project management are well documented, and the literature offers many useful project management toolsets (Besner \& Hobbs, 2012; Pinto \& Slevin, 1989; White \& Fortune, 2002), which indicates that managerial practices influence R\&D project success (Tatikonda \& Rosenthal, 2000). Among these practices are included the norms, routines, traditions and rules that guide the behaviour of the practitioner (Blomquist, Hällgren, Nilsson, \& Söderholm, 2010). Very often, project managers learn, from their own experiences in the field, which practices are best to improve performance specifications. Moreover, they try to standardize project management practices according to their past experiences, especially if they work at the firm for a long time.

'Lessons learned' is an extremely important term in project management, and is defined as the key project experiences that have general business relevance for future projects (Project Management Institute, 1987). As a result of organizational learning, firms bring in management improvements (Huber, 1991; Levitt \& March, 1988; Walsh \& Rivera Ungson, 1991), and these are able to provide sustainable competitive advantages if used properly (Carrillo, Ruikar, \& Fuller, 2013). Nevertheless, a R\&D project is frequently based on specific knowledge. When that knowledge is not directly applicable to other ongoing projects, organizational amnesia begins (project-to-project). Although the progress in understanding and improving inter-project learning looks to be slight (Hartmann \& Dorée, 2015), the reasons for project amnesia were collected by Schindler \& Martin (2003) and they are classified in four groups -time, motivation, discipline, and skills- in order to point out the key success factors of project learning. However, mostly of these elements are based on tacit knowledge or inside routines performed by employees, and it is difficult to make them available for the entire organization because they are transferable throughout the extensive personal contact and systematic interaction of employees (Goffin \& Koners, 
2011). In the case of product innovation, Koners \& Goffin (2007) point out the need of further research to identify how employees can generate tacit and explicit ( perfectly identified, codified and easily accessed) knowledge and support project-to-project learning.

Although management improvements are difficult to systematize and incorporate into managerial processes, and are rarely used successfully when they lead to organizational changes (Paranagamage, Carrillo, Ruikar, \& Fuller, 2012), they have been proved to be effective for learning in a double loop (Argyris \& Schön, 1978). In the first loop, the project team might learn how to approach tasks and deal with a new situation. In the second loop, the organization might increase its performance and its stock of knowledge for managing future projects, by learning beyond the project. Our research adopts a wider view of managerial practices in project management, because we analyse significant practices observed in European firms (Turner, Ledwith, \& Kelly, 2010), and also how organizations learn from past experience in earlier projects inside the firms (Daghfous, 2004); in addition, we look at the relationship between the project manager's experience in the R\&D field and the firm's AC. Considering the accumulated knowledge of the project manager, both scientific-technical knowledge and managerial experience, one would expect to find a positive effect on project achievement and business value (Reich, Gemino, \& Sauer, 2013). The influence in every AC dimension should be positive and significant.

\subsection{Absorptive capacity and knowledge context}

Knowledge is overwhelmingly the most important productive resource nowadays (Grant, 1997). The major and most differentiated skills required to develop R\&D projects are based on a specific knowledge of the organization, in order to carry out the tasks of developing new products, as well as the new processes and new organizational procedures required. R\&D should spur people on to identify and assimilate knowledge and exploit it for a commercial purpose (Cohen \& Levinthal, 1989a, p. 569). In this sense, a firm might 
generate innovations even though the level of knowledge and expertise needed for a successful development of its projects was not available at the beginning. According to Spithoven, Clarysse, \& Knockaert (2011) and Todorova \& Durisin (2007), the concept of AC was further developed to explain why internal R\&D is progressively more focused on the creation of the prior knowledge necessary to effectively absorb external ideas.

In relation to identifying and assimilating knowledge, PAC has been positively associated with the creation of radical innovations (Ritala \& Hurmelinna-Laukkanen, 2013). Several studies have shown a direct relationship between PAC and innovation performance, which is also an antecedent of RAC (Kim, 1998; Matusik \& Heeley, 2005; Zahra \& George, 2002), although in the recent empirical research of Leal-Rodríguez et al. (2014), they have not found evidence of PAC and innovation performance's relation. Realized absorptive capacity (RAC) includes the capability to transform and exploit knowledge. The transformation capability consists of the ability to adapt external knowledge in order to integrate it within projects (Rundquist, 2012) and combine it with in-house knowledge, whereas the exploitation capability involves the ability to obtain sustainable competitive advantages based on that knowledge (Escribano et al., 2009). AC is composed of the interaction between PAC and RAC. However every dimension should contribute in a different way to project performance, innovation and business results (Schmidt, 2010). To describe that situation, the recent study of Popaitoon \& Siengthai (2014) carried out in Indian firms is an example that shows that PAC is positively related to project performance in the long-run, while RAC is related in the short-run. On the basis of these considerations, AC cannot study as a unique variable; each one of their dimensions should be studied separately, as well as their relation with the dynamic capabilities of the firms in order to improve the R\&D project's performance.

The turbulence of the environment and the technology intensity of firms have increased in all sectors of activity. Nevertheless, an exposure to knowledge does not guarantee that a firm will have a higher level of AC (Matusik \& Heeley, 2005) and R\&D intensity might not 
have significantly influence AC for intra- and inter-industry knowledge (Schmidt, 2010). There are other factors that affect innovation management (Tid \& Bessant, 2009); the most common aspects include the company's size, the nature of the national innovation system, the lifecycle of technology and industry, particularly their speed and turbulence, the degree of novelty, the stakeholders' role, etc.

Characteristics of the external environment, such as sophistication or R\&D orientation, influence the firm's functions and performance (Khandwalla, 1977). The knowledge context might be considered to be the firm's internal environment. In as much as the learning is contextually embedded in the social activity (Hartmann \& Dorée, 2015), it is the knowledge collected from different parts of the firm in an organized manner, as well as the feedback that employees receive, that could have a positive influence on the firm's AC (Matusik \& Heeley, 2005). A project has a much better environment if it has attracted the interest and support of all the relevant stakeholders of the organization (Martínez Sánchez \& Pérez Pérez, 2002). Thus the context should be created and renewed as consequence of actions, and this configures a dynamic capability to improve the firm's performance (Laursen \& Foss, 2003; Miotti \& Sachwald, 2003; Teece et al., 1998; Urgal, Quintás, \& Arévalo Tomé, 2011). Since the knowledge context increases the successful transfer within the firm (Cummings \& Teng, 2003), several authors consider a project to be a temporary organization, and the knowledge that is effectively transferred to future projects might then take advantage of previous efforts, whilst the organization is learning and improving its AC.

\subsection{The contribution of R\&D project management to absorptive capacity}

There are discoveries in R\&D laboratories that sometimes remain idle until the owner decides it is time to exploit them (Tukel, Kremic, Rom, \& Miller, 2011), even though the projects that generate them are not isolated in the firm. Consequently, the provisional findings, as much as the final results might help to convince internal or external customers, 
support an application for funds or influence the allocation of internal resources among different projects and programmes. Barczak, Griffin, \& Kahn (2009) found that the best firms emphasize and integrate their innovation strategy across all levels of the firm. In this way, every R\&D project should be aligned with the strategy and the capabilities developed by previous projects, and this is also crucial for innovation outcomes (Davies \& Brady, 2000). Moreover, the progress of the project influences the firm's AC, although scholars have not yet fully explained how management activities can influence each AC dimension (Koza \& Lewin, 1998; Volberda, Foss, \& Lyles, 2010). Organizations must be able to generate and assimilate new knowledge in order to keep up with market changes, and to include that knowledge in the development of current projects (Eriksson, 2012; Mccarthy \& Gordon, 2011; O’Reilly \& Tushman., 2004).

There are three goals of project management from a learning perspective: delivering a successful project, building capabilities, and delivering a series of successful projects (Kotnour, 1999). The first of these seems even more complex in the R\&D context than for other kinds of projects, because the progress achieved during project implementation could be as useful as the project when completed according to its initial specification. The second goal, project capabilities in combination with dynamic capabilities, frequently leverages and enhances innovation (Biedenbach, 2011), and it can also provide greater flexibility for environmental adaptation. Some managerial practices are the result of using collective knowledge to solve organizational problems, or to improve efficiency in internal and external modus operandi, and they therefore contribute to the generation of organizational capabilities. Knowledge and managerial practices that are developed as part of R\&D projects provide organizational learning and sustainable capabilities to the firm to stimulate progress to the third goal, that is, the delivery of successive successful projects (Brady \& Davis, 2004).

Project management practices considered by practitioners (collected, reviewed and improved periodically in bodies of knowledge, as PMBOK or UNE-EN 160.001) and the 
practices analysed by scholars (published in scientific journals of international reputation) put together share their concern to manage the R\&D projects for the best interest of every one of the stakeholders. The project managers are aware of the challenges for doing new things based on their prior knowledge after they have to access to new information. Thus, learning from past experiences may improve project performance, enable the building of capabilities, and also prevent the repetition of past mistakes.

From an individual firm's perspective, projects could be considered as modes of organizing and learning (Weick, 1995), and the creation of organizational capabilities to manage them has been a prime subject for theoretical and empirical studies. However, new potential knowledge is outside firms, and external relations with institutions and experts facilitate the access to new knowledge for current and future purposes, and could increase the firm's AC. Our research aims to establish whether learning integrated into the project management process can generate capability within the firm for managing new knowledge in the future. To respond to this question, it is not enough to carry out a quantitative study, because of the nature of knowledge and the flows of knowledge inside the projects and the firm (Gasik, 2011; Howells, 1996; Polanyi, 1966; Snider \& Nissen, 2003). A dialogical model provides a heterogeneous framework to consider the theoretical and practical perspectives, in case to obtain a positive answer to our research question 'Can project management practices improve the AC of a firm in any way?', a wider research in terms of geography and organizational idiosyncrasy should be accomplished in the future in order to respond an open endless question like this: how the R\&D Project Management practices can improve the firm's AC? 


\section{Methods}

\subsection{Research methodology}

The increasing number of conferences and co-written papers between scholars and practitioners are 'living proof' of the mutual effort to bridge the gap between research and practice. According to Rynes (2007), the implementation of existing research findings into everyday management requires appropriate communication. Moreover, the findings must be applicable, and the knowledge transferred and its translation should be useful for the management. Managers reflect on how to use learning to operate and adapt their capacities, experience and intuition effectively in complex project environments, and on the pragmatic application of theory in practice (Winter, Andersen, Elvin, \& Levene, 2006). The dialogical model is used to manage productive dialogues and deal with antagonistic and complementary positions (Morin, 1992; Tsoukas, 2009). According to Avernier's conceptualization, this model consists of five steps or activities (Avenier \& Cajaiba, 2012).

The first activity has been set out in the previous section, in which we explained the theoretical gap and put forward the research question. We revised prior literature about the management of innovation, knowledge and projects (specifically R\&D projects), and also standards from professional associations and standards accreditation bodies which applies to the firm's environment in the same topics. Section 2 contains comprehensive descriptions of the current situation and support the formulation of the research question.

The second activity collects the practitioners' experiences, and accordingly we interviewed fifteen project managers in companies, as well as experts in R\&D management who were academics, research and technology transfer agents and consultants. All of them were Spanish and had connections with the northeast region of Spain arising from prior collaborations, associations and lectures. The scholars and experts were connected to the University of Zaragoza and regional government agencies, were supporters of innovation, and they were invited to participate voluntarily. To accomplish the third step, fourteen 
scholars and experts were interviewed to construct the conceptual knowledge that we connected to the existing literature. The review of the questionnaire for the quantitative study helps the research by providing validity and integrity for the questions and also for the ways of measuring them. The companies that took part in the study are, on average, twenty-five years old, and their mean number of employees is fifty-five (medium size). Table 1 also includes information about the sectors in which the firms operate, and the experts who were interviewed.

Table 1. Summary of interviews to practitioners and scholars

The third activity of the dialogical model consists of the construction of conceptual knowledge to generalize the local knowledge as part of the epistemology or general knowledge. The quantitative analysis was developed to test the research question according to the existing literature, to accomplish a rigorous study. Although the Avernier \& Parmentier Cajaiba's dialogical model is a epistemological framework based on qualitative method (Avenier \& Thomas, 2013), there are explorative studies that used questionnaires (i.e. Isaksen \& Akkermans, 2011; Swamidass \& Winch, 2002). In this respect, many of qualitative factors are related on a Likert-type scale (Balachandra \& Friar, 1997, p. 286) as we use to measure the AC's levels. AC has been shown by several studies as a multidimensional, multilevel construct, and that their dimensions build upon each other (Lane, Koka, \& Pathak, 2006; Nemanich, Keller, Vera, \& Chin, 2010; Todorova \& Durisin, 2007; Zahra \& George, 2002). The third activity of the dialogical model also states the need to publish the findings in academic journals or conference papers by connecting the local 
knowledge to extant literature. Therefore we explain the reliability and the internal validity of our study. For reliability, we justified the methodological decisions made: the expert's characteristics, the selected sample and data collection and the empirical data. For internal validity, we justified the methodological tools that were used in terms of 'why' and 'how' in this section dedicated to research methods.

The fourth and fifth steps include communicating the results to practitioners and activating the knowledge. To accomplish these last steps, we have carried out activities like visiting five firms and communicating the results to all the firms that provided feedback to us about the relationships in the analysis. However these visits are not enough to put the elaborate knowledge into practical use, which is a primary purpose in the framework (Avenier, 2009, p. 160). Companies were invited to attend a presentation about this research and our results, and at least three of them did so in order to provide external validity. These responses' analysis was made by contrasting the results of the questionnaires and their opinions about the general results of our study. We are looking for financial support for a new project to develop a practical guide, to spread the research results also among academics.

\subsection{Sample and data collection procedures}

The quantitative analysis is based on a survey that, first of all, collects data about the description of the respondent company and the project manager. Secondly, the survey asks about the characteristics of the organizational context of the knowledge and how external knowledge is identified, assimilated, transformed and exploited. And thirdly, the data covers the characteristics of projects and the firm's management practices. As a whole, the data provide information to allow an analysis of the relationship between project management practices and $\mathrm{AC}$, within a particular knowledge context. 
An e-mail survey was carried out, between the last quarter of 2011 and the first half of 2012, of Spanish firms that had accomplished R\&D projects in the period 2005-2010 on their own or with external collaboration. The Technological Development Agency (CDTI) provided information about the projects it had supported in the Middle Ebro valley. The biggest research centre in the area is the University of Zaragoza, which published information about its partnerships between 2005 and 2010 (inclusive). We created a database with information about these 788 companies, and 177 of them offered information about the R\&D director or contact data for the general manager. Fifteen of these firms helped to design the quantitative analysis (included in table 1) and an interview to obtain the results. The questionnaires were sent to each company's R\&D project manager, and after a third reminder 71 companies had returned questionnaires, of which 69 were valid. Although the response rate $(38.98 \%)$ is low, it is still a good rate for a mail survey, and we believe that the sample is still a good representation of the population. Other studies based on firms and their strategic decisions have had a similar response rate and number of respondents (Goll \& Rasheed, 1997; Hitt \& Tyler, 1991). Companies are usually reluctant to participate in this kind of study (Flatten, Engelen, Zahra, \& Brettel, 2011; Gartner \& Thomas, 1993; Lefebvre \& Lefebvre, 1992), and it could even be considered to be complicated for them, especially considering the critical economic situation during the study period, with firms being burdened by financial difficulties and R\&D budget cuts. The third wave of responses was tested for a non-response bias by comparing the early and late respondents (Armstrong \& Overton, 1977), and we found no statistically significant differences in the percentage of employees devoted to R\&D activities, the innovation effort and the net profit on sales, indicating that the sample is representative of the population. Besides the data included in the questionnaires, interviews were held with fifteen practitioners to collect their experiences of R\&D project management, and this provided qualitative information that was transcribed by the researchers after the visit, for subsequent analysis. 


\subsection{Sample characteristics}

The respondents were project managers or heads of R\&D departments, and in small firms they were CEOs and technical managers. On average they had directed fifteen projects and worked in R\&D for more than ten years, although the variation here is high. They were young (30\% were under thirty) graduates and postgraduates $(94 \%)$, although they had not been certified as project managers by any professional association (94.2\%). Data provided by a single informant may have the risk of common variance, i.e. one project manager could contaminate all the measurements in a common direction, and we therefore ran the Harman test (Podsakoff \& Organ, 1986) for the variables included in the model. Using factor analysis (principal components) we obtained several factors, with the first of these explaining less than $30 \%$ of the total variance, which rules out the possibility of common variance.

Table 2 includes the description of the sample and the R\&D projects examined. The projects were developed between 2005 and 2010. The distribution of firms by size indicates that $86.96 \%$ are small and medium-sized enterprises (micro-entities are $14.49 \%$ of the total firms), and $13.04 \%$ are large companies. The main industries involved in our study are lowtechnology (52.17\%), although high-technology industries are also well represented (31.88\%). Firms in peripheral regions can benefit from proximity to and good communications with central regions (Martínez-Sánchez, 1992), and in our study those central regions are Madrid and Catalonia. The aims of the R\&D projects were product development (48.31\%), new or improved processes $(30.09 \%)$ and organizational innovation $(21.60 \%)$. Most of the funds to carry out the R\&D projects were provided by the companies themselves $(74.19 \%)$, since public and foreign aid is less than $25 \%$. The funds were used to pay for salaries $(69.86 \%)$, stock $(18.97 \%)$ and fungibles $(4.65 \%)$, and other expenses include consultancy and patent registration fees (6.65\%). 
Table 2. Descriptive information about companies and R\&D projects (2010)/characteristics of sampled firms and sampled R\&D projects (per cent).

\subsection{Variable measurement}

The baseline assumption in this paper is that $A C$ is a multidimensional construct. Similarly, managerial practices and learning from past experience were measured with multi-item scales that were derived from studies that have previously been validated, or that we created with the support of the expert group. Each item included in the constructs was rated on a Likert-type scale. The item scales used to measure all variables in this study were validated using principal component factor analysis for a unidimensional construct. The Kaiser-Meyer-Olkin values of all measures were higher than the recommended value of 0.60 (Kaiser, 1974), and the Barlett's Test of Sphericity was statistically significant at the 1\% level (Barlett, 1954). All our constructs passed both tests, and this indicates that our data is adequate for the analysis. In order to assess the internal consistency of the scales, we used Cronbach's alpha and the common threshold value of 0.70 (Nunnally, 1978). Table 3 shows that all the Cronbach's alpha values were acceptable. The questionnaire constructs were operationalized and measured as follows (see Appendix):

(a) Each of the dependent variables is one of the AC dimensions: potential absorptive capacity (PAC) and realized absorptive capacity (RAC), differentiating between the ability to transform knowledge (RAC1) and the ability to exploit knowledge (RAC2). The items for these variables occupied the second section of the questionnaire, and 
all are based on the scale validated by Flatten et al., (2011). The fourteen-item measure of $\mathrm{AC}$ assessed the processes of identification and assimilation (using seven items to measure PAC), transformation (using four items for RAC1) and exploitation (using three items for RAC2). The unit of analysis was the firm, and the scale went from 1 ('never used') to 7 ('always used'). The AC construct of Flatten et al. was used for the questionnaire because its purpose was to develop reflective measures for the four $A C$ dimensions. Although they divided PAC into two constructs (acquiring, and assimilating, the external knowledge), our collected data showed that PAC was a single variable. We accept this grouping because there is no academic agreement so far about the optimum number of dimensions for accessing and using knowledge (Todorova \& Durisin, 2007). The seminal paper on AC by Cohen and Levinthal acknowledged three dimensions. This is an example of an occasion on which theoretical studies and practical approaches show differences that authors could explain. This variable was calculated by the mean of all items included.

(b) The independent variables for exploring how managerial practices and internal flows of knowledge are related to AC were asked in several sections of the survey. Widespread project management practices were measured by a twelve-item construct. The scale was developed according to De Vellis (2003) suggestions, except that the item 'pool generation' was taken from the study by Turner et al. (2010). The essential practices that the project managers identified in Turner's 2010 study were checked with the practitioners and academics (see Section 3.1). First, the academics considered the inclusion of validation items and helped to determine the format for measurement, which was an ordinal scale between 1 ('never used') and 5 ('always used'). Secondly, the pilot sample of fifteen firms evaluated the items to produce a final scale. This was validated for the items, and the integrity was higher than the recommended value (Cronbach's alpha was 0.829). This variable was calculated by the mean of all items included. 
(c) Learning from past experience is a variable to test the effect of lessons learned in previous projects with a four-item construct (Daghfous, 2004). We used an ordinal scale between 1 ('never used') and 5 ('always used'). This variable provides information about the firm's procedure for analysing and recapping on lessons learned, and about whether the lessons have a potential impact for the whole organization in the future ('a systematic way of identifying potential changes in all business functions', Daghfous, 2004). This variable was calculated by the mean of all items included.

(d) The management style for the project and perception of the risk, cost and deliverables have been considered in prior studies, because of their relevance and impact on the project (Eweje, Turner, \& Müller, 2012; Müller \& Turner, 2007; Verner, Overmyer, \& McCain, 1999). Our measure of the project manager's experience was based on objective items, such as the ratio between the number of projects managed and the years of experience of R\&D.

(e) Knowledge context is based on Matusik and Heeley's (2005) five-item scale from 1 ('never used') to 5 ('always used'). This variable was calculated by the mean of all items included.

(f) The control variables are firm experience (the log of the years since creation) and innovation effort (the R\&D spending as percentage of sales for the year 2010). The organizational experience interacts with the context to create knowledge (Argote, Miron-spektor, \& Gan, 2009), however lower managerial experience has been related, in the innovation field, to flexibility, specialization and learning in previous empirical research (Jiménez-Jiménez \& Sanz-Valle, 2011; Rosenbusch, Brinckmann, \& Bausch, 2011). R\&D spending and financial resources have also been considered as AC precursors (Cohen \& Levinthal, 1990; Murovec \& Prodan, 2009). 
Table 3. Descriptive statistics: means, standard deviations, correlations (Spearman's Rho) and Cronbach's alpha (in bold and italics)

\section{Analysis}

This research explores the relationship between project management practices and AC, and how learning is integrated into the project management process to enhance future organizational capabilities. Organizations are always learning, and our results show that R\&D project management practice is related to $A C$. Quantitative data analysis has given us a way to construct the research model based on the practitioner's experience, allowing a deeper investigation into the relationships between project managerial practices for R\&D and absorptive capacity.

We carried out three regression analyses, since this methodology is, in general, suitable for identifying the effects of the behaviour of certain variables (explanatory) on the behaviour of others (explained) (Berk, 2008).

Table 4. Linear regression of project management and AC

Table 4 shows that knowledge context is significantly $(p<0.01)$ and positively related to all dimensions of $A C(\beta=0.491 ; \beta=0.378 ; \beta=0.449)$, and therefore that potential and realized 
capacities are beneficiaries of an organized and coordinated structure with easy flows of knowledge. However, managerial practices have a different impact on every dimension, because learning from past experience $(\beta=0.251)$ and the project manager's experience $(\beta=0.205)$ are significantly and positively related to potential absorptive capacity, while project management practices are only related to realized absorptive capacity $(\beta=0.297$; $\beta=0.431)$.

The qualitative analysis of the five interviews showed the effect of different $A C$ for firms on how they manage their R\&D projects and how learning from completed R\&D projects is included in their organizational procedures. We combined the information supplied by practitioners and contrasted this with the quantitative results. Firstly, practitioners expressed their opinions about the general results, and whether they make a plausible picture of their reality or if they had another explanation for our study's results. Secondly, we showed their particular situation and their differences regarding the complete sample in order to ask them for an explanation about the reasons for those differences (new economical instabilities, difficulties to afford new projects, etc.). Every one of the practitioner's disagreements and reasons that they found for explaining the differences were noted and analysed both separately and with the general results. Among the most significant discoveries we found that some project managers accept the huge importance of project specifications, even though in the R\&D area these tend to be relatively lax, even more in cutting-edge products. Almost half of our sample firms had developed new product projects before.

Most of practitioners included in our study's interpretation very quickly explained the relationship between project management practices and absorptive capacity when they described the results, and this particularly relates to the reason why project management practices are not related to potential absorptive capacity. The general opinion is that firms begin R\&D projects with their current internal knowledge. If the firm has to access new knowledge as the project develops, this diverts resources from the original plan and 
influences the task of producing the deliverables. Thus project management practices are used to transform internal knowledge and to apply it to solve the challenges of the project, so realizing absorptive capacity. From this perspective, an R\&D project team has no interest in accessing new knowledge from outside the firm unless this is absolutely necessary.

The knowledge context influences access not only to tacit knowledge, but also to explicit knowledge. The high statistical significance of knowledge context in the three models shows its importance inside the organizations. This evidence provides a new insight into the interrelationship between overall project management and the specific management of project knowledge. The project manager's experience and the lessons learned from R\&D projects configure a kind of latent capability. This is internal to the company and the project team and, in particular, the project manager. He or she gives appropriate direction, and his or her practices in managing a project should incorporate every kind of external knowledge to be used inside the firm in order to improve the current project performance. Firms with a flexible and open knowledge context could increase the success of future projects beyond the current expectation, with the support of the experience of the project manager, collecting learning from past experience and creating good practice for managing projects. 


\section{Discussion}

This paper supports previous research about the generation of dynamic capabilities and project-based learning, although our study is exploratory. It let us build a knowledge framework that can be used by practitioners and academics, and can be applied to every kind of R\&D project.

Absorptive capacity contributes to an increase in innovation results and it is considered a dynamic capability, so it should be used to modify short-term competitive positions and to build long-term competitive advantages (Escribano et al., 2009; Gebauer et al., 2012; Teece et al., 1998). Project-based learning takes into account an essential difference between learning by absorption and learning by reflection (Carbrough, Bresnen, Edelman, \& Laurent, 2004). On the one hand, learning by absorption is related to AC because it is part of the dynamic process of project realization, and project management practices can be improved during the execution of the project. From our research, project management practices enable the transformation and exploitation of previously acquired external knowledge, because of the positive relationship found between this variable and the realized absorptive capacity. On the other hand, learning by reflection includes practices that contribute to improving the ability to generate knowledge and to make it explicit and capable of being shared within the organization. This can be translated into new projects carried out by practitioners, in which they can share their individual experiences (Ayas, 1996; Zollo \& Winter, 2002). However our findings show that lessons learned and the project manager's experience are only positively related to potential capacity. According to the current academic thinking that projects are learning organizations (Ahern, Leavy, \& Byrne, 2014; Cook \& Brown, 1999), absorptive capacity might be a means to improve organizational learning. 
Capturing the lessons learned from R\&D projects is very frequently done by these firms and is generally appreciated by all the organizations in the survey. However this process is poorly performed because of a lack of time and resources, and constraints on incentives (Williams, 2008), and evidence of its contribution to project success cannot be found in the short-run, but only over the long-run. Mueller's (2014) study shows that the sharing of knowledge among project teams is vital to organizational learning. In the same way, our interviews with managers after the quantitative analysis (in order to contrast our results with their experience) indicated that they consider that learning from past experiences after a reflective process, with the ongoing learning being included in the diary, is more valuable for project performance. Most project analyses are carried out at the very end, and some practical lessons are incorporated to avoid future problems. For instance, in military operations an After Action Report is compulsory and comes before any critical judgement in which the lessons learned become explicit knowledge. Thus, the project teams unconsciously incorporate new lessons into their current project management practices (tacit knowledge), and this could be a reason why we found no relationship with realized absorptive capacity, but only with potential absorptive capacity. Following this reasoning, Dutton, Turner, \& Lee-Kelley (2014) showed that knowledge acquisition and distribution mostly took place through social contacts and informal means of communication, rather than by formal processes. Thus, in an ongoing project, learning from recent experience is incorporated instead, and this is a crucial difference between R\&D projects and other projects.

Most of the existing research on project-based learning tends to focus on product innovation (Tidd, 2003), and previous research on process innovation demonstrates that captured and transferred learning is often tacit, intangible and part of the context of the previous situation (Bresnen, Edelman, Newell, Scarbrough, \& Swan, 2003). However, our research takes a broad perspective on how project managers learn management skills by experience (Turner, Keegan, \& Crawford, 2000), and our findings show the positive 
relationship with the ability to identify and assimilate external knowledge. Project managers note the importance of collecting the lessons learned from a project (Kotnour, 1999), and our results also find a positive relationship with potential absorptive capacity.

Even though the numerical results show that the relationship between ways to create tacit knowledge, such as the experience of project managers or the lessons learned from past experience, and the absorptive capacity phase of each firm, when the acquired knowledge is inside the firm, cannot influence on every absorptive dimension, this could improve future project performance, according to the managers' responses. Recently, Ebers \& Maurer (2014) have shown, in their study of European countries, that potential and realized absorptive capacity had partially different antecedents.

A general conclusion for our study is that generating absorptive capacity is essential, although the achievement of absorptive capacity is not one of the project's aims and would increase the time and costs. However, R\&D management can contribute to improving absorptive capacity within the organization, as our results show, as it is a dynamic capability difficult to create in others. Our study can contribute towards developing a new framework in which to consider project success and to consider how the influence of managerial practices in this success gives a firm an absorptive capacity for knowledge. By checking the usefulness of a scale to measure how well most common project management practices are used in European countries (based on Turner et al. 2010), we have provided a new academic indicator for this issue. This can help future empirical studies in Europe that use quantitative models for measuring project management practices in a multidimensional way.

The seminal work of Cohen and Levinthal (1989) distinguished three absorptive capacity dimensions. However, Zahra and George (2002) proposed separating out potential capacity because they considered that identifying knowledge outside the firm was something that had to be achieved before the knowledge could be acquired. Currently, there is no 
consensus among researchers about the number of dimensions of absorptive capacity, and there are constant proposals for its reconceptualization (Jiménez-Barrionuevo, GarcíaMorales, \& Molina, 2011; Todorova \& Durisin, 2007). Although there are theoretical and empirical differences about the number of dimensions, the meaning of the concept is common in the existing research. Zahra and George (2002) explained that companies with greater PAC are more likely to sustain a competitive advantage, since they possess greater flexibility for reconfiguring their resources and capabilities quickly and at a low cost. In contrast, firms with higher RAC are more likely to achieve a competitive advantage through the development of new products and new processes. Our study provides new insights about the concept, with empirical evidence about the AC construct.

Holzmann (2012) pointed out that learning from projects in organizations is based on knowledge transfer, since the knowledge acquired in one project is transmitted to other projects, and it is often used in other contexts. Certainly, the influence of organizational culture on the process of effective knowledge transfer in project-based organizations is required, in order to prepare the organizational culture to accept, adopt, and utilize new knowledge. In this sense, project managers can promote the knowledge transfer since the organization and the knowledge context accompanied the process (Ajmal \& Koskinen, 2008), although our empirical research shows that their contribution is only related to knowledge acquisition. Results from other scholars also suggest that potential absorptive capacity may not be related to knowledge acquisition (Leal-Rodriguez et al, 2015). This may indicate that favouring informal relationships at work is a helpful way to store lessons learned from projects, as well as improve the firm's knowledge stock and managerial practices.

Several limitations of our study should be noted. First, the small size of the sample and the cross-sectional nature of the study mean that further replication by other empirical studies is required. It would be interesting to link each $R \& D$ project management practice to a specific measure of project performance, particularly to project success. We have developed our 
arguments to establish links between managerial practices in the $R \& D$ project and absorptive capacity, according to the knowledge context inside the organization. For instance, it would be possible to use longitudinal measures of project management practices and the evolution of absorptive capacity and look at their impact on the project results. Thus it would be possible to expand our measure of absorptive capacity to include the possibility of adopting managerial practices used in R\&D projects by other organizations. The second limitation of our study is the measurement of the project manager's experience by the ratio between the number of projects the manager has run and his or her years of experience. Our research design has ignored information about any special abilities developed for complex projects, and the depth of knowledge for radical innovations. These experiences could provide additional information about leadership, management style and character. Information provided by the project team could also be useful. Finally after analysing the question of "whether" project management practices improve the absorptive capacity of the firm, our research might continue by analysing "how" these practices could actually improve absorptive capacity. This research should be very useful for project managers indeed.

Despite these limitations, we believe that our study offers important insights for the field of R\&D project management and access to external knowledge. The results confirm the positive contribution of project management to absorptive capacity, and show that different procedures to manage R\&D projects influence every dimension. The importance of knowledge context is also highlighted. High-intensive knowledge environments provide firms with higher levels of absorptive capacity. 


\section{References}

Ahern, T., Leavy, B., \& Byrne, P. J. (2014). Knowledge formation and learning in the management of projects: A problem solving perspective. International Journal of Project Management, 32(8), 14231431. doi:10.1016/j.ijproman.2014.02.004

Ajmal, M. M., \& Koskinen, K. U. (2008). Knowledge Transfer in Project-Based Organizations: An Organizational Culture Perspective. Project Management Journal, 39(1), 7-15.

Argote, L., Miron-spektor, E., \& Gan, R. (2009). Organizational Learning: From Experience to Knowledge. Organizational Science, 22(5), 1123-1137

Argyris, C., \& Schön, D. (1978). Organizational Learning: A theory of action perspective. Reading, MA: Addison-Wesley.

Armstrong, J., \& Overton, T. (1977). Estimating Non-Response Bias in Mail Surveys. Journal of Marketing, 14(3), 396-402.

Armstrong, C. E., \& Shimizu, K. (2007). A Review of Approaches to Empirical Research on the Resource-Based View of the Firm. Journal of Management, 33(6), 959-986. doi:10.1177/0149206307307645

Arora, A., \& Gambardella, A. (1994). Evaluating technological information and utilizing it. Journal of Economic Behavior \& Organization, 24(1), 91-114. doi:10.1016/0167-2681(94)90055-8

Avenier, M. J. (2009). A Methodological Framework for Constructing Generic Knowledge with Intended Value both for Academia and Practice. In B. Borgger \& O. Eikeland (Eds.), Turning to Practice with Action Research (pp. 141-178). Frankfurt: Peter Lang publishers.

Avenier, M. J., \& Cajaiba, A. P. (2012). The Dialogical Model: Developing Academic Knowledge for and from Practice. European Management Review, 9(4), 199-212. doi:10.1111/j.17404762.2012.01038.x

Avenier, M. J., \& Thomas, C. (2013). What Kinds of Qualitative Methods Are Adapted To Doing Research in Which Epistemological Frameworks? In XXII Conférence International de Management Stratégique (pp. 1-30). Clermont-Ferrand.

Ayas, K. (1996). Professional project management: a shift towards learning and a knowledge creating structure. International Journal of Project Management, 14(3), 131-136. doi:10.1016/02637863(95)00080-1 
Bakker, R. M., Cambré, B., Korlaar, L., \& Raab, J. (2011). Managing the project learning paradox: A set-theoretic approach toward project knowledge transfer. International Journal of Project Management, 29(5), 494-503. doi:10.1016/j.ijproman.2010.06.002

Balachandra, R., \& Friar, J. H. (1997). Factors for Success in R\&D Projects and New Product Innovation: A Contextual Framework. IEEE Transactions on Engineering Management, 44(3), 276287.

Barczak, G., Griffin, A., \& Kahn, K. B. (2009). PERSPECTIVE: Trends and Drivers of Success in NPD Practices: Results of the 2003 PDMA Best Practices Study. Journal of Product Innovation Management, 26(1), 3-23. doi:10.1111/j.1540-5885.2009.00331.x

Barlett, J. R. (1954). A note for multiplying factors for various chi square approximations. J. R. Stat. Soc., 16, 296-298.

Barney, J. (1991). Firm Resources and Sustained Competitive Advantage. Journal of Management, 17(1), 99-120. doi:10.1177/014920639101700108

Barney, J. B. (2001). Resource-based theories of competitive advantage : A ten- year retrospective on the resource-based view. Journal of Management, 27, 643- 650. doi:10.1177/014920630102700602

Berk, S. (2008). Statistical Learning from a Regression Perspective. Manchester: Springer.

Besner, C., \& Hobbs, B. (2012). An Empirical Identification of Project Management Toolsets and a Comparison Among Project Types. Project Management Journal, 43(5), 24-46. doi:10.1002/pmj.21292

Biedenbach, T. (2011). The Power of Combinative Capabilities: Facilitating the outcome of frequent innovation in pharmaceutical R\&D projects. Project Management Journal, 42(2), 63-80. doi:10.1002/pmj

Biedenbach, T., \& Müller, R. (2012). Absorptive, innovative and adaptive capabilities and their impact on project and project portfolio performance. International Journal of Project Management, 30(5), 621-635. doi:10.1016/j.ijproman.2012.01.016

Blomquist, T., Hällgren, M., Nilsson, A., \& Söderholm, A. (2010). Project-as-practice: In search of project management research that matters. Project Management Journal, 41(1), 5-16. doi:10.1002/pmj.20141

Brady, T., \& Davis, A. (2004). Building Project Capabilities: From Exploratory to Exploitative Learning. Organization Studies, 25(9), 1601-1621. doi:10.1177/0170840604048002

Bresnen, M. ., Edelman, L. ., Newell, S., Scarbrough, H. ., \& Swan, J. . (2003). Social practices and the management of knowledge in project environments. International Journal of Project Management, 21(3), 157-166. doi:10.1016/S0263-7863(02)00090-X

Carbrough, H., Bresnen, M., Edelman, L., \& Laurent, S. (2004). The Processes of Project-based Learning: An Exploratory Study. Management Learning, 35(4), 491-506. 
Carrillo, P., Ruikar, K., \& Fuller, P. (2013). When will we learn? Improving lessons learned practice in construction. International Journal of Project Management, 31(4), 567-578. doi:10.1016/j.ijproman.2012.10.005

Cassiman, B., \& Veugelers, R. (2006). In Search of Complementarity in Innovation Strategy: Internal R\&D and External Knowledge Acquisition. Management Science, 52(February 2015), 68-82. doi:10.1287/mnsc. 1050.0470

Cohen, W. M., \& Levinthal, D. A. (1989a). Innovation and Learning: The Two Faces of R \& D. The Economic Journal, 99(397), 569-596. doi:10.2307/2233763

Cohen, W. M., \& Levinthal, D. A. (1989b). The Two Faces of R\&D. The Economic Journal, 99(397), 569-596.

Cohen, W. M., \& Levinthal, D. A. (1990). Absorptive Capacity: A New Perspective on Learning and Innovation. Administrative Science Quarterly, 35, 128-152. doi:10.2307/2393553

Cook, S. D. N., \& Brown, J. S. (1999). Bridging Epistemologies: The Generative Dance Between Organizational Knowledge and Organizational Knowing. Organization Science, 10(4), 381-400. doi:10.1287/orsc.10.4.381

Cummings, J. L., \& Teng, B. (2003). Transferring R\&D knowledge: the key factors affecting knowledge transfer success. Journal of Engineering and Technology Management, 20(1-2), 39-68. doi:10.1016/S0923-4748(03)00004-3

Daghfous, A. (2004). An empirical investigation of the roles of prior knowledge and learning activities in technology transfer. Technovation, 24, 939-953. doi:10.1016/S0166-4972(03)00059-2

Danneels, E. (2002). The dynamics of product innovation and firm competences. Strategic Management Journal, 23(12), 1095-1121. doi:10.1002/smj.275

Davies, A., \& Brady, T. (2000). Organisational capabilities and learning in complex product systems: towards repeatable solutions. Research Policy, 29, 931-953. doi:10.1016/S0048-7333(00)00113-X

De Vellis, R. F. (2003). Scale developmet. Theory and applications. EEUU: Thousand Oaks.

Dutton, C., Turner, N., \& Lee-Kelley, L. (2014). Learning in a programme context: An exploratory investigation of drivers and constraints. International Journal of Project Management, 32(5), 747758. doi:10.1016/j.ijproman.2014.02.003

Dvir, D., \& Shenhar, A. J. (1996). Toward a typological theory of project management. Research Policy, 25, 607-632.

Ebers, M., \& Maurer, I. (2014). Connections count: How relational embeddedness and relational empowerment foster absorptive capacity. Research Policy, 43(2), 318-332. doi:10.1016/j.respol.2013.10.017

Eisenhardt, K. M., \& Martin, J. A. (2000). Dynamic capabilities: what are they? Strategic Management Journal, 1121, 1105-1121. 
Eriksson, P. E. (2012). Exploration and exploitation in project-based organizations: Development and diffusion of knowledge at different organizational levels in construction companies. International Journal of Project Management, 31(3), 333-341. doi:10.1016/j.ijproman.2012.07.005

Escribano, A., Fosfuri, A., \& Tribó, J. A. (2009). Managing external knowledge flows: The moderating role of absorptive capacity. Research Policy, 38(1), 96-105. doi:10.1016/j.respol.2008.10.022

Eweje, J., Turner, R., \& Müller, R. (2012). Maximizing strategic value from megaprojects: The influence of information-feed on decision-making by the project manager. International Journal of Project Management, 30(6), 639-651. doi:10.1016/j.jproman.2012.01.004

Flatten, T. C., Engelen, A., Zahra, S. A., \& Brettel, M. (2011). A measure of absorptive capacity: Scale development and validation. European Management Journal, 29(2), 98-116. doi:10.1016/j.emj.2010.11.002

Fosfuri, A., \& Tribó, J. A. (2008). Exploring the antecedents of potential absorptive capacity and its impact on innovation performance. Omega, 36(2), 173-187. doi:10.1016/j.omega.2006.06.012

Gartner, W. B., \& Thomas, R. J. (1993). Factors affecting new product forecasting accuracy in new firms. Journal of Product Innovation Management, 10(1), 35-52. doi:10.1016/0737-6782(93)90052-R

Gasik, S. (2011). A model of project knowledge management. Project Management Journal, 42(3), 23-44. doi:10.1002/pmj.20239

Gebauer, H., Worch, H., \& Truffer, B. (2012). Absorptive capacity, learning processes and combinative capabilities as determinants of strategic innovation. European Management Journal, 30(1), 57-73. doi:10.1016/j.emj.2011.10.004

Goffin, K., \& Koners, U. (2011). Tacit Knowledge, Lessons Learnt, and New Product Development. Journal of Product Innovation Management, 28(2), 300-318. doi:10.1111/j.1540-5885.2010.00798.x

Goll, I., \& Rasheed, A. M. a. (1997). Research Notes and Communications Rational Decision-Making and Firm Performance: the Moderating Role of Environment. Strategic Management Journal, 18(April 1995), 583-591.

Grant, R. M. (1997). The Knowledge-based View of the Firm: Implications for Management Practice. Long Range Planning, 30(3), 450-454.

Gunasekaran, A. (1997). Essentials of international and joint R\&D projects. Technovation, 17(11-12), 637-647. doi:10.1016/S0166-4972(97)00043-6

Hartmann, A., \& Dorée, A. (2015). Learning between projects: More than sending messages in bottles. International Journal of Project Management, pp. 341-351. Elsevier Ltd and International Project Management Association. doi:10.1016/j.jproman.2014.07.006

Helfalt, C. E., Finkelstein, S., Mitchell, W., Peteraf, M. A., Singh, H., Teece, D. J., \& Winter, S. G. (2007). Dynamic capabilities. Understanding strategic change in organizations. Blackwell Publishing.

Hitt, M. A., \& Tyler, B. B. (1991). Strategic decision models: Integrating different perspectives. Strategic Management Jounal, 12, 327-351. doi:10.1002/smj.4250120502 
Holzmann, V. (2012). A meta-analysis of brokering knowledge in project management. International Journal of Project Management, 31(1), 2-13. doi:10.1016/j.jproman.2012.05.002

Howells, J. (1996). Tacit knowledge. Technology Analysis \& Strategic Management, 8(2), 91-106. doi:10.1080/09537329608524237

Huber, G. P. (1991). Organizational Learning: The Contributing Processes and the Literatures. Organization Science, 2(1), 88-115.

Isaksen, S. G., \& Akkermans, H. J. (2011). Creative climate: A leadership lever for innovation. Journal of Creative Behavior, 45(3), 161-187. doi:10.1002/j.2162-6057.2011.tb01425.x

Jansen, J. J. P., Van Den Bosch, F. A. J., \& Volberda, H. W. (2005). Managing potential and realized absorptive capacity: How do organizational antecedents matter? Academy of Management Journal, 48(6), 999-1015. doi:10.5465/AMJ.2005.19573106

Jiménez-Barrionuevo, M. M., García-Morales, V. J., \& Molina, L. M. (2011). Validation of an instrument to measure absorptive capacity. Technovation, 31(5-6), 190-202. doi:10.1016/j.technovation.2010.12.002

Jiménez-Jiménez, D., \& Sanz-Valle, R. (2011). Innovation, organizational learning, and performance. Journal of Business Research, 64(4), 408-417. doi:10.1016/j.jbusres.2010.09.010

Kaiser, H. F. (1974). An index of factorial simplicity. Psychometrika, 39(1), 31-36.

Khandwalla, P. N. (1977). The Design of Organizations. New York: Harcourt, Brace, Jovanovich.

Kim, L. (1998). Crisis Construction and Organizational Learning: Capability Building in Catching-up at Hyundai Motor. Organization Science, 9(4), 506-521. doi:10.1287/orsc.9.4.506

Killen, C. P., Jugdev, K., Drouin, N., \& Petit, Y. (2012). Advancing project and portfolio management research: Applying strategic management theories. International Journal of Project Management, 30(5), 525-538. doi:10.1016/j.jproman.2011.12.004

Koners, U., \& Goffin, K. (2007). Learning from post-project reviews: a cross-case analysis. Journal of Product Innovation Management, 24(3), 242-258.

Koskinen, K. U. (2011). Problem absorption as an organizational learning mechanism in projectbased companies: Process thinking perspective. International Journal of Project Management, 30(3), 308-316. doi:10.1016/j.jproman.2011.08.008

Kotnour, T. (1999). A Learning Framework for Project Management. Project Management Journal, 30(2), 32-38.

Koza, M. P., \& Lewin, A. Y. (1998). The Co-Evolution of Strategic Alliances. Organization Science, 9(3), 255-264. doi:10.1287

Lane, P. J., \& Lubatkin, M. (1998). Relative absorptive capacity and interorganizational learning. Strategic Management Journal, 19(5), 461-477. doi:10.1002 
Lane, P. J., Koka, B. B., \& Pathak, S. (2006). The reification of absorptive capacity: a critical review and rejuvenation of the construct. Academy of Management Review, 31(4), 833-863.

Laursen, K., \& Foss, N. J. (2003). New human resource management practices , complementarities and the impact on innovation performance. Cambridge Journal of Economics, 27(April 2000), 243263.

Leal-Rodríguez, A. L., Roldán, J. L., Ariza-Montes, J. a., \& Leal-Millán, A. (2014). From potential absorptive capacity to innovation outcomes in project teams: The conditional mediating role of the realized absorptive capacity in a relational learning context. International Journal of Project Management, 32(6), 894-907. doi:10.1016/j.ijproman.2014.01.005

Lefebvre, E., \& Lefebvre, L. A. (1992). Firm innovativeness and CEO characteristics in small manufacturing firms. Journal of Engineering and Technology Management, 9(3-4), 243-277. doi:10.1016/0923-4748(92)90018-Z

Levitt, B., \& March, J. G. (1988). Organizational Learning Barbara Levitt ; James G . March. Annual Review of Sociology, 14, 319-340.

March, J. G. (1991). Exploration and exploitation in organizational learning. Organization Science, 2(1), 71-87.

Martínez Sánchez, Á., \& Pérez Pérez, M. (2002). R \& D project efficiency management in the Spanish industry. International Journal of Project Management, 20(20), 545-560.

Martínez-Sánchez, Á. (1992). Regional Innovation and Small High Technology Firms in Peripheral Regions. Small Business Economics, 4, 153-168.

Matusik, S. F., \& Heeley, M. B. (2005). Absorptive Capacity in the Software Industry: Identifying Dimensions That Affect Knowledge and Knowledge Creation Activities. Journal of Management, 31(4), 549-572. doi:10.1177/0149206304272293

Mccarthy, I. P., \& Gordon, B. R. (2011). Achieving contextual ambidexterity in R \& D organizations : a management control system approach. R\&D Management, 41(3), 240-258.

Miotti, L., \& Sachwald, F. (2003). Co-operative R\&D: why and with whom? An integrated framework of analysis. Research Policy, 32, 1481-1499.

Mitchell, V. L. (2006). Knowledge integration \& IT Project Performance. MIS Quarterly, 30(4), 919939.

Morin, E. (1992). From the concept of system to the paradigm of complexity. Journal of Social and Evolutionary Systems, 15(4), 371-385. doi:10.1016/1061-7361(92)90024-8

Mueller, J. (2014). A specific knowledge culture: Cultural antecedents for knowledge sharing between project teams. European Management Journal, 32(2), 190-202. doi:10.1016/j.emj.2013.05.006 
Müller, R., \& Turner, R. (2007). The Influence of Project Managers on Project Success Criteria and Project Success by Type of Project. European Management Journal, 25(4), 298-309. doi:10.1016/j.emj.2007.06.003

Murovec, N., \& Prodan, I. (2009). Absorptive capacity, its determinants, and influence on innovation output: Cross-cultural validation of the structural model. Technovation, 29(12), 859-872. doi:10.1016/j.technovation.2009.05.010

Nemanich, L. a., Keller, R. T., Vera, D., \& Chin, W. W. (2010). Absorptive Capacity in R\&D Project Teams: A Conceptualization and Empirical Test. IEEE Transactions on Engineering Management, 57(4), 674-688. doi:10.1109/TEM.2009.2037736

Nunnally, J. C. (1978). Psychometric Theory, Second ed. NewYork: McGrew-Hill.

Ojo, A. O., Raman, M., Chong, S. C., \& Chong, C. W. (2014). Individual antecedents of ACAP and implications of social context in joint engineering project teams: a conceptual model. Journal of Knowledge Management, 18(1), 177-193. doi:10.1108/JKM-08-2013-0332

O’Reilly, \& Tushman., M. L. (2004). The Ambidextrous Organization. Harvard Business Review, 82(4), 74-81.

Paranagamage, P., Carrillo, P., Ruikar, K., \& Fuller, P. (2012). Lessons learned practices in the UK construction sector: current practice and proposed improvements. Engineering Project Organization Journal, 2(4), 216-230. doi:10.1080/21573727.2012.681643

Pinto, J. K., \& Slevin, D. P. (1989). Critical Success Factors In R \& D Projects. Research Technology Management, 32(1), 31-35.

Podsakoff, P. M., \& Organ, D. W. (1986). Self-Reports in Organizational Research: Problems and Prospects. Journal of Management, 12, 531-544.

Polanyi, M. (1966). The Tacit Dimension. London, Routledge: University of Chicago Press.

Popaitoon, S., \& Siengthai, S. (2014). The moderating effect of human resource management practices on the relationship between knowledge absorptive capacity and project performance in project-oriented companies. International Journal of Project Management, 32(6), 908-920. doi:10.1016/j.ijproman.2013.12.002

Project Management Institute. (1987). Guía del PMBOK®.

Reich, B. H., Gemino, A., \& Sauer, C. (2013). How knowledge management impacts performance in projects: An empirical study. International Journal of Project Management. doi:10.1016/j.ijproman.2013.09.004

Ritala, P., \& Hurmelinna-Laukkanen, P. (2013). Incremental and Radical Innovation in CoopetitionThe Role of Absorptive Capacity and Appropriability. Journal of Product Innovation Management, 30(1), 154-169. doi:10.1111/j.1540-5885.2012.00956.x 
Rohrbeck, R., \& Schwarz, J. O. (2013). The value contribution of strategic foresight: Insights from an empirical study of large European companies. Technological Forecasting and Social Change, 80(8), 1593-1606. doi:10.1016/j.techfore.2013.01.004

Rosenbusch, N., Brinckmann, J., \& Bausch, A. (2011). Is innovation always beneficial? A metaanalysis of the relationship between innovation and performance in SMEs. Journal of Business Venturing, 26(4), 441-457. doi:10.1016/j.jbusvent.2009.12.002

Rundquist, J. (2012). The Ability To Integrate Different Types of Knowledge and Its Effect on Innovation Performance. International Journal of Innovation Management, 16(02), 1250014. doi:10.1142/S1363919612003794

Rynes, S. L. (2007). Editor's afterword. Let's create a tipping point: what academics and practitioners can do, alone and together. Academy of Management Journal, 50(5), 1046-1054.

Schindler, M., \& Martin, J. . (2003). Harvesting project knowledge: a review of project learning methods and success factors. International Journal of Project Management, 21(3), 219-228. doi:10.1016/S0263-7863(02)00096-0

Schmidt, T. (2010). Absorptive Capacity - One Size Fits All ? A Firm-level Analysis of Absorptive Capacity for Different Kinds of Knowledge. Managerial and Decision Economics, 18, 1-18. doi:10.1002/mde

Sitkin, S. B., Sutcliffe, K. M., \& Schroeder, R. G. (1994). Distinguishing Control from Learning in Total Quality Management: A Contingency Perspective. The Academy of Management Review, 19(3), 537. doi: $10.2307 / 258938$

Snider, K. F., \& Nissen, M. E. (2003). Beyond the body of knowledge: a knowledge-flow approach to project management. Project Management Journal, 34(2), 4-12.

Spithoven, A., Clarysse, B., \& Knockaert, M. (2011). Building absorptive capacity to organise inbound open innovation in traditional industries. Technovation, 31(1), 10-21. doi:10.1016/j.technovation.2010.10.003

Spithoven, A., \& Teirlinck, P. (2015). Internal capabilities, network resources and appropriation mechanisms as determinants of R\&D outsourcing. Research Policy, 44(3), 711-725. doi:10.1016/j.respol.2014.10.013

Swamidass, P. M., \& Winch, G. W. (2002). Exploratory study of the adoption of manufacturing technology innovations in the USA and the UK. International Journal of Production Research. doi:10.1080/00207540210137549

Tatikonda, M. V, \& Rosenthal, S. R. (2000). Successful execution of product development projects: Balancing firmness and flexibility in the innovation process. Journal of Operations Management, 18(4), 401-425. doi:10.1016/S0272-6963(00)00028-0

Teece, D. J., Pisano, G., \& Shuen, A. (1998). Dynamic capabilities and strategic management. Strategic Management Journal, 18(7), 509-533. 
Tid, J., \& Bessant, J. (2009). Managing Innovation (4th ed.). New York: JOHN WILEY \& SONS LTD.

Tidd, J. (2003). Development of Novel Products Through Intraorganizational and Interorganizational Networks. Journal of Product Innovation Management, 12(4), 307-322. doi:10.1111/15405885.1240307

Todorova, G., \& Durisin, B. (2007). Absorptive capacity: valuing a reconceptualization. Academy of Management Review, 32(3), 774-786. doi:10.5465/AMR.2007.25275513

Tsoukas, H. (2009). A dialogical approach to the creation of new knowledge in organizations. Organization Science, 20(6), 941-957. doi:10.1287/orsc.1090.0435

Tukel, O. I., Kremic, T., Rom, W. O., \& Miller, R. J. (2011). Knowledge-salvage practices for dormant R\&D projects. Project Management Journal, 42(1), 59-72. doi:10.1002/pmj.20207

Turner, J. R. (2009). The handbook of project based management: Leading Strategic Change in Organizations (3th ed., p. 473). London: McGraw-Hill.

Turner, J. R., Keegan, A., \& Crawford, L. (2000). Learning by experience in the project-based organisation, 2000. In Proj. Manage. Inst. (PMI) Res. Conf. Newtown Square, PA.

Turner, J. R., Ledwith, A., \& Kelly, J. (2010). Project management in small to medium-sized enterprises: Matching processes to the nature of the firm. International Journal of Project Management, 28(8), 744-755. doi:10.1016/j.jproman.2010.06.005

UNE166.001. (2006). UNE 166001:2006. Gestión de la I+D+i: Requisitos de un proyecto de I+D+i.

Urgal, B., Quintás, M. Á., \& Arévalo Tomé, R. (2011). Conocimiento tecnológico, capacidad de innovación y desempeño innovador: el rol moderador del ambiente interno de la empresa. Cuadernos de Economía Y Dirección de La Empresa, 14(1), 53-66. doi:10.1016/j.cede.2011.01.004

Verner, J. M., Overmyer, S. P., \& McCain, K. W. (1999). In the 25 years since The Mythical ManMonth what have we learned about project management? Information and Software Technology, 41, 1021-1026. doi:10.1016/S0950-5849(99)00077-4

Volberda, H. W., Foss, N. J., \& Lyles, M. a. (2010). Absorbing the Concept of Absorptive Capacity: How to Realize Its Potential in the Organization Field. Organization Science, 21(4), 931-951. doi:10.1287/orsc. 1090.0503

Walsh, J. P., \& Rivera Ungson, G. (1991). Organizational Memory. Academy of Management Review, 16(1), 57-91.

Wang, C. L., \& Ahmed, P. K. (2007). Dynamic Capabilities: A Review and Research Agenda. International Journal of Management Review, 9(1), 31-51.

Weick, K. E. (1995). Sensemaking in Organizations. Thousand Oaks, CA: Sage.

Wernerfelt, B. (1984). A Resource-Based View of the Firm. Strategic Management Journal, 5(2), 171-180. 
White, D., \& Fortune, J. (2002). Current practice in project management $\boxminus$ an empirical study. International Journal of Project Management, 20, 1-11.

Williams, T. (2008). How Do Organizations Learn Lessons From Projects-And Do They? IEEE Transactions on Engineering Management, 55(2), 248-266. doi:10.1109/TEM.2007.912920

Winter, M., Andersen, E., Elvin, R., \& Levene, R. (2006). Focusing on business projects as an area for future research: An exploratory discussion of four different perspectives. International Journal of Project Management, 24(8), 699-709. doi:10.1016/j.ijproman.2006.08.005

Zahra, S. A., \& George, G. (2002). Absorptive Capacity: A Review, Reconceptualization, and Extension. The Academy of Management Review, 27(2), 185. doi:10.2307/4134351

Zollo, M., \& Winter, S. G. (2002). Deliberate learning and the evolution of dynamic capabilities. Organization Science, 13(3), 339-351. 


\section{Apendix A}

\section{Questionnaire items and variables}

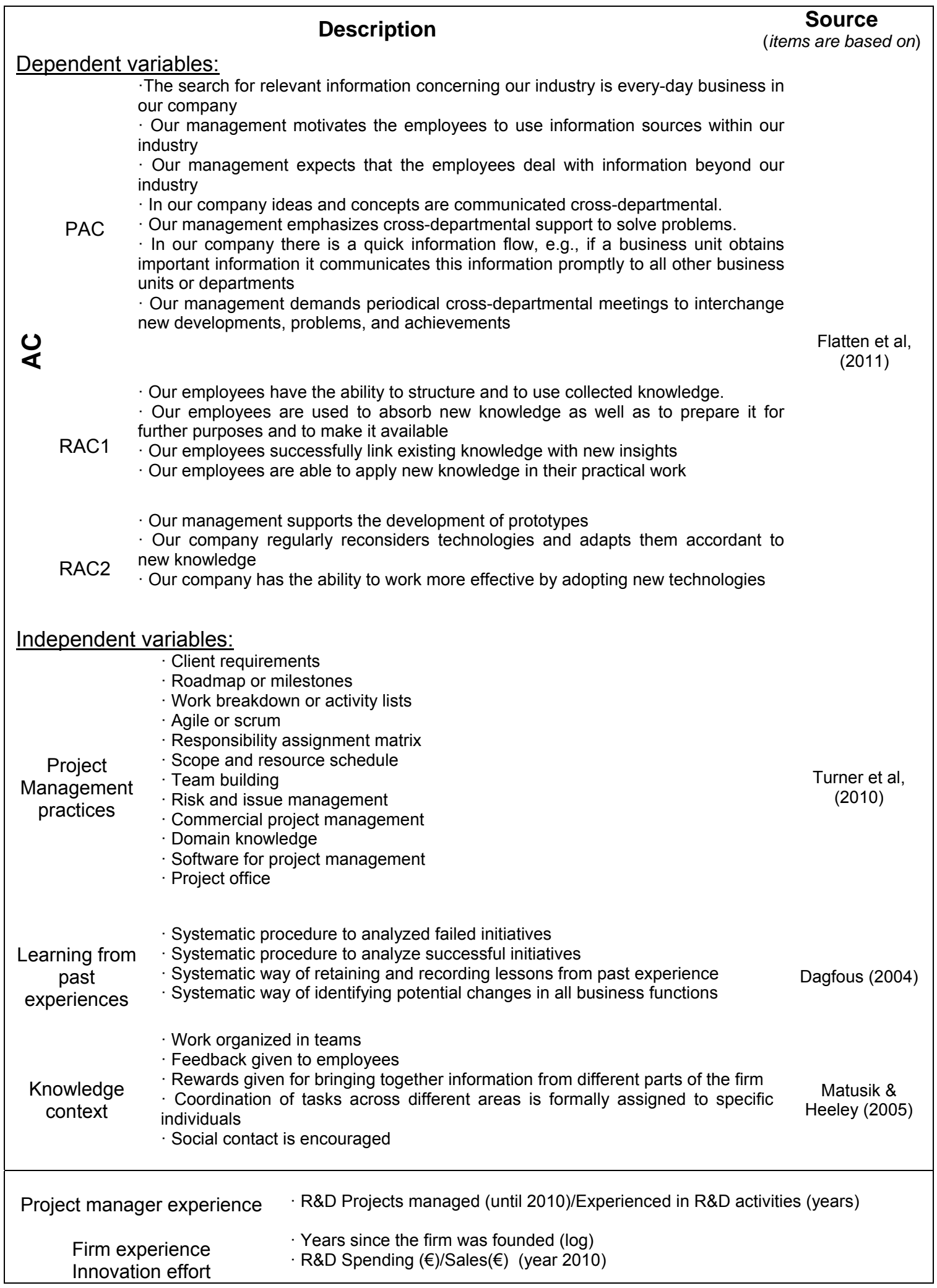


Table 1. Summary of interviews to practitioners and scholars

\begin{tabular}{|c|c|c|c|c|c|c|}
\hline \multicolumn{3}{|c|}{ PRACTITIONERS } & & \multicolumn{3}{|c|}{ SCHOLARS AND R\&D EXPERTS } \\
\hline & Firm's Activity & Size & Years & & No. & jiews \\
\hline 1 & ICT & 18 & 15 & 1 & Faculties: & \\
\hline 2 & ICT & 24 & 19 & & Business Administration & 2 \\
\hline 3 & ICT & 6 & 8 & & Marketing & 2 \\
\hline 4 & MANUFACTURING & 35 & 19 & & Project Engineering & 2 \\
\hline 5 & ICT & 92 & 9 & & Manufacturing Process & 1 \\
\hline 6 & ICT & 60 & 35 & & & \\
\hline 7 & CONSTRUCTION & 30 & 49 & 2 & Managers in research institutions & \\
\hline 8 & BIOTECHNOLOGY & 15 & 6 & & Technology Transfer Office (TTO) & 2 \\
\hline 9 & MANUFACTURING & 50 & 16 & & $\begin{array}{l}\text { Technology Transfer Spanish } \\
\text { Network }\end{array}$ & 1 \\
\hline 10 & CONSULTANCY & 125 & 14 & & Regional Cluster & 1 \\
\hline 11 & MANUFACTURING & 37 & 49 & & Research Institute & 1 \\
\hline 12 & AGRO-FOOD & 39 & 27 & & & \\
\hline 13 & AGROO-FOOD & 184 & 31 & 3 & Senior Consultant & 2 \\
\hline 14 & RETAILING & 38 & 37 & & & \\
\hline 15 & SERVICIOS & 80 & 34 & & & \\
\hline & Mean & 55,53 & 24,53 & & & \\
\hline
\end{tabular}


Table 2. Descriptive information about companies and R\&D projects (2010) /characteristics of sampled firms and sampled R\&D projects (per cent).

\begin{tabular}{|c|c|c|c|c|c|c|}
\hline \multicolumn{2}{|l|}{ FIRMS } & \multicolumn{5}{|c|}{ R\&D PROJECTS } \\
\hline \multicolumn{2}{|l|}{ Size (number of employees): } & \multicolumn{5}{|l|}{ Project goal } \\
\hline - Small $(-50)$ & 60.87 & \multicolumn{3}{|c|}{ - New or improved Product } & \multicolumn{2}{|l|}{48.31} \\
\hline - Medium (51-250) & 26.09 & \multicolumn{3}{|c|}{ - New or improved Process } & \multicolumn{2}{|l|}{30.09} \\
\hline$\cdot \operatorname{Big}(+251)$ & 13.04 & \multicolumn{3}{|c|}{ - Organisational innovation } & \multicolumn{2}{|l|}{21.60} \\
\hline Total & 100 & \multicolumn{3}{|c|}{ Total } & \multicolumn{2}{|l|}{100} \\
\hline \multicolumn{2}{|l|}{ Technology intensity } & \multicolumn{5}{|c|}{ Source and application of fund } \\
\hline$\cdot$ High & 31.88 & \multicolumn{2}{|l|}{ Fund origin } & \multicolumn{3}{|c|}{ Application } \\
\hline - Medium & 15.94 & - Own & 74.19 & $\cdot P \epsilon$ & rsonal & 69.86 \\
\hline - Low & 52.18 & - National public aid & 23.16 & $\cdot \ln$ & entories & 18.97 \\
\hline Total & 100 & - Foreign sector aid & 1.62 & $\cdot \mathrm{Fu}$ & ngible & 6.52 \\
\hline & & - Other firms & 0.02 & $\cdot$ Ot & er & 4.65 \\
\hline & & Total & 100 & Tot & & 100 \\
\hline
\end{tabular}


Table 3. Descriptive statistics: means, standard deviations, correlations (Spearman's Rho) and Cronbach's alpha (in bold and italics)

\begin{tabular}{|c|c|c|c|c|c|c|c|c|c|c|c|}
\hline & & Mean & SD & 1 & 2 & 3 & 4 & 5 & 6 & 7 & 8 \\
\hline 1 & PAC & 4.67 & 1.49 & 0.902 & & & & & & & \\
\hline 2 & RAC1 & 4.85 & 1.50 & $.666^{* *}$ & 0.907 & & & & & & \\
\hline 3 & RAC2 & 5.18 & 1.59 & $.685^{* *}$ & $.689 *$ & 0.871 & & & & & \\
\hline 4 & $\begin{array}{l}\text { Project Manage- } \\
\text { ment Practices }\end{array}$ & 3.64 & 0.83 & $.264^{*}$ & $.439 * *$ & $.419 * *$ & 0.829 & & & & \\
\hline 5 & $\begin{array}{l}\text { Learning from past } \\
\text { experiences }\end{array}$ & 3.03 & 1.64 & $.465^{* *}$ & $.402^{* *}$ &, $.258^{*}$ & $.373 * *$ & 0.846 & & & \\
\hline 6 & Knowledge Context & 4.19 & 1.56 & $.657^{* *}$ & $.538^{* *}$ & $.470 * *$ & .159 & $.467^{* *}$ & 0.731 & & \\
\hline 7 & $\begin{array}{l}\text { Project Manager } \\
\text { Experience }\end{array}$ & 5.10 & 1.32 & .169 & 0,04 & .114 & -.133 & .071 & .065 & & \\
\hline 8 & Firm Experience & 5.21 & 1.47 & $-.328 * *$ & $-.341 * *$ & -.201 & -.075 & -.191 & $-.373^{* *}$ & -.026 & \\
\hline 9 & Innovation Effort & 1.47 & 2.00 & -.079 & .067 & -.002 & .162 & -.040 & .018 & .148 & .230 \\
\hline
\end{tabular}

Level of significance: ${ }^{*} p<0.1,{ }^{*} p<0,01$ 
Table 4. Linear regression of project management and AC

\begin{tabular}{|c|c|c|c|}
\hline Variables & $\begin{array}{c}\text { PAC } \\
\text { Model } 1\end{array}$ & $\begin{array}{c}\text { RAC1 } \\
\text { Model } 2\end{array}$ & $\begin{array}{c}\text { RAC2 } \\
\text { Model } 3\end{array}$ \\
\hline Firm experience & $\begin{array}{l}-0.062 \\
(0.639)\end{array}$ & $\begin{array}{c}-0.200 \\
(1.880)+\end{array}$ & $\begin{array}{l}-0.023 \\
(0.218)\end{array}$ \\
\hline Innovation effort & $\begin{array}{l}-0.086 \\
(0.933)\end{array}$ & $\begin{array}{c}-0.49 \\
(-0.486)\end{array}$ & $\begin{array}{l}-0.075 \\
(0.747)\end{array}$ \\
\hline Knowledge context & $\begin{array}{c}0.491 \\
(4.614)^{\star \star}\end{array}$ & $\begin{array}{c}0.378 \\
(3.237)^{\star \star}\end{array}$ & $\begin{array}{c}0.449 \\
(3.844)^{\star \star}\end{array}$ \\
\hline Project management practices & $\begin{array}{c}0.083 \\
(0.850)\end{array}$ & $\begin{array}{c}0.297 \\
(2.774)^{\star \star}\end{array}$ & $\begin{array}{c}0.431 \\
(4.037)^{\star \star}\end{array}$ \\
\hline Learning from past experiences & $\begin{array}{c}0.251 \\
(2.268)^{*}\end{array}$ & $\begin{array}{c}0.097 \\
(0.798)\end{array}$ & $\begin{array}{l}-0.018 \\
(0.151)\end{array}$ \\
\hline Project manager experience & $\begin{array}{c}0.205 \\
(2.247)^{*}\end{array}$ & $\begin{array}{l}0.067 \\
(0.670)\end{array}$ & $\begin{array}{c}0.142 \\
(1.429)\end{array}$ \\
\hline$F($ full modell) & $11.414^{\star \star}$ & $7.797^{* *}$ & $8.104^{\star *}$ \\
\hline Adjusted $R^{2}$ & $0.479 * \star$ & $0.378^{\star \star}$ & $0.389 * *$ \\
\hline
\end{tabular}

Standardized significant beta coefficients; $t$-values in parentheses.

Level of significance: ${ }^{+} p<0.1{ }^{\star} p<0.05,{ }^{* *} p<0.01$ 